\title{
PENGARUH EKSTRAK LOMPONG (Colocasia esculenta L. Schoot) 45 MENIT PENGUKUSAN TERHADAP AKTIVITAS FAGOSITOSIS DAN KADAR NO (NITRIT OKSIDA) MENCIT BALB/C SEBELUM DAN SESUDAH TERINFEKSI LISTERIA MONOCYTOGENES
}

\author{
Mubayinah, Hesti Murwani Rahayuningsih*) \\ Program Studi Ilmu Gizi Fakultas Kedokteran Universitas Diponegoro \\ Jl.Dr.Sutomo No.18, Semarang, Telp (024) 8453708, Email : gizifk@undip.ac.id
}

\begin{abstract}
ABSTRACK
Background: The leaves and stems of lompong (Colocasia esculenta L. Shoot) consumed as a vegetables. Lompong extract contained flavonoids, saponins, tannins, and triterpenoids. Flavonoids increased cellular immune response. The immune response seen from phagocytic activity and NO level.

Objective: Analyze the effect of 45 minutes steamed lompong extract 13mg/20gBW on phagocytic activity and NO level of macrophages before and after infected by Listeria monocytogenes $10^{5} \mathrm{CFU}$.

Method: This study was a true experimental with the post-test with randomized control group design. The subject of the study were 21 male Balb/c mices and 10 weeks old, 15-20 grams. They were divided into 3 groups: K group received standart diet; $P 1$ group received 45 minutes steamed lompong extract before infected by Listeria monocytogenes and $P 2$ group received 45 minutes steamed lompong extract after infected by Listeria monocytogenes. $K, P 1$, and $P 2$ groups induced by Listeria monocytogenes on the fourth day. The data were analyzed by independent t-test.

Result: There was significant difference of phagocytic activity between $P 1-K(p=0,001)$ group but there was no significant difference between $P 2-K(p>0,05)$ group. There were no significant differences of NO level between $P 1-K$ and $P 2-K$ groups. There was an increase in the average of phagocytic activity and NO level on before infected group. After infected group only there was increse on the average of phagocytic activity.

Conclusion: 45 minutes steamed lompong extract increases macrophages phagocytic activity and NO level in before infected Balb/c mice group which is as preventive function.
\end{abstract}

Keywords: Lompong (Colocasia esculenta L. Schoot), phagocytic macrophage, nitric oxide

\section{ABSTRAK}

Latar belakang: Batang dan daun lompong (Colocasia esculenta l. schoot) dapat dikonsumsi sebagai sayuran. Ekstrak lompong mengandung senyawa flavonoid, saponin, tanin, dan triterpenoid. Kandungan flavonoids dapat meningkatkan respon imun selluler. Respon imun dapat dilihat dari aktivitas fagositosis dan kadar NO (Nitrit Oksida). Tujuan: Menganalisis pengaruh ekstrak lompong 45 menit pengukusan sebanyak 0,13mg/20gBB terhadap aktivitas fagositosis dan kadar NO makrofag sebelum dan sesudah terinfeksi Listeria monocytogenes $10^{5}$ CFU.

Metoda: Jenis penelitian true experimental dengan the post test with randomized control group design. Sampel penelitian 21 ekor mencit Balb/c jantan dan berumur 10 minggu dengan berat badan 15-20 gram. Mencit dibagi menjadi 3 kelompok yaitu kelompok K mendapatkan pakan standar; kelompok P1 mendapatkan ekstrak lompong 45 menit pengukusan sebelum diinfeksi Listeria monocytogenes dan kelompok P2 mendapatkan ekstrak lompong 45 menit pengukusan setelah diinfeksi Listeria monocytogenes. Kelompok $K, P 1$, dan P2 diinduksi Listeria monocytogenes pada hari keempat. Uji beda menggunakan uji independent t test.

Hasil: Terdapat perbedaan aktivitas fagositosis yang signifikan antara kelompok $P 1-K(p=0,001)$ tetapi tidak terdapat perbedaan antara kelompok P2-K ( $p>0,05)$. Tidak ada perbedaan yang signifikan kadar NO antara kelompok P1-K dan P2-K. Terdapat peningkatan rerata indeks fagositosis dan kadar NO pada kelompok perlakuan sebelum diinfeksi. Kelompok perlakuan setelah diinfeksi hanya terdapat peningkatan rerata indeks fagositosis.

Simpulan: Ekstrak lompong 45 menit pengukusan dapat meningkatkan rerata indeks fagositosis dan kadar NO makrofag pada mencit Balb/c kelompok perlakuan sebelum diinfeksi yang berfungsi sebagai preventif.

Kata Kunci: Lompong (Colocasia esculenta l. schoot), fagositosis makrofag, Nitrit Oksida

\section{PENDAHULUAN}

Lompong (Colocasia esculenta L. Schoot) merupakan tanaman yang dapat dikonsumsi sebagai makanan pokok karena umbi yang dihasilkan, daun dan batang yang dapat digunakan sebagai sayuran. Lompong termasuk dalam family Araceae. ${ }^{1} \mathrm{Di}$ Indonesia, lompong dapat dijumpai hampir di seluruh kepulauan baik tumbuh liar maupun dibudidayakan. $^{2}$

Kandungan senyawa aktif yang ada dalam ekstrak daun lompong adalah alkaloid, saponin, tanin, flavonoid dan polifenol. Flavonoid yang ada di ekstrak daun lompong antara lain orientin, isoorientin, isovitexin, vicenin-2, orientin 7oglukosida, isovitexin 3 O-glukosida, vitexin $\mathrm{X}$ -

${ }^{*}$ Penulis Penanggungjawab 
Oglukosida, leteolin 7-O-glukosida. Ekstrak daun lompong juga menunjukkan senyawa anthosianin seperti sianidin-3-glukosida, pelargonidin-3glukosida dan sianidin-3-rhamnosida yang memiliki aktifitas sebagai antioksidan. ${ }^{3}$

Lompong biasanya dikonsumsi setelah mengalami proses pengukusan, perebusan, penggorengan, blanching, dan pressure cooking. Proses pemasakan efektif untuk meningkatkan penyerapan zat gizi dan mengurangi kadar oksalat. ${ }^{4}$ Kadar oksalat ini dapat menyebabkan gatal-gatal dan iritasi pada kulit setelah dikonsumsi. ${ }^{1,4}$ Proses perebusan pada suhu $90^{\circ} \mathrm{C}$ selama 45 menit dapat mereduksi kalsium oksalat rata-rata $70 \% .^{5}$ Penelitian ini menggunakan proses pengukusan daripada proses perebusan karena untuk meminimalkan zat gizi yang hilang saat proses pemasakan. ${ }^{5}$

Ekstraksi dilakukan setelah lompong dikukus yang bertujuan untuk memperoleh zat aktif dari sari serbuk lompong. Proses ekstraksi menggunakan metode sokletasi dengan pelarut etanol. ${ }^{6}$ Etanol digunakan sebagai pelarut polar yang dapat melarutkan senyawa yang bersifat polar seperti flavonoid.?

Kandungan senyawa flavonoid yang ada dalam lompong dapat meningkatkan respon imun. Respon imun tubuh dapat dilihat dari aktivitas makrofag yang termasuk sistem seluler dan produksi Nitrit Oksida (NO) sebelum atau setelah infeksi. Infeksi dalam tubuh dapat disebabkan karena bakteri, jamur, dan virus. ${ }^{8}$

Bakteri yang digunakan untuk merespon imun selluler alamiah adalah bakteri intraselluler. ${ }^{9}$ Listeria monocytogenes merupakan bakteri intraseluler yang biasanya digunakan untuk mengetahui respon imun selluler. ${ }^{9,10}$ Listeria monocytogenes dapat hidup di dalam makrofag dan dapat menghindari mekanisme bakterisidal makrofag. ${ }^{10}$ Bakteri intraselluler menstimulasi makrofag mensekresikan IL-12 yang mengaktifkan sel Natural Killer (NK), menstimulasi perkembangan sel Th-1 dan mengaktifasi sel $\mathrm{T}$ $\mathrm{CD}^{+}$. Ketiga sel yang teraktifkan tersebut mensekresikan interferon gamma (IFN- - ) yang akan mengaktifkan makrofag sehingga makrofag tersebut dapat membunuh bakteri intraselluler. ${ }^{9}$

Kemampuan makrofag dalam membunuh bakteri tergantung pada senyawa oxygen dependent (hydrogen peroxidase, singlet oxygen, hydroxy radicals) dan senyawa oxygen independent (lisosome, lactoferin, cationic protein). Makrofag juga bertanggung jawab terhadap produksi NO. ${ }^{9}$ Produksi nitrit oksida diawali dari terpaparnya makrofag oleh lipopolisakarida dari bakteri sehingga jalur produksi Reactive Nitrogen Intermediat (RNI) terinduksi. Senyawa RNI yang dihasilkan melalui jalur produksi tersebut dapat merubah senyawa-senyawa amin menjadi bentuk $N$ nitroso compounds (NOC) yang bersifat sitotoksik. Meningkatnya kadar NO makrofag menunjukkan adanya peningkatan aktivitas makrofag dalam proses killing bakteri intraseluler. ${ }^{8}$

Konsumsi sayur lompong untuk manusia dewasa dengan berat badan $70 \mathrm{~kg}$ yaitu sekitar 150 g/hari yang digunakan sebagai dasar dosis pemberian ekstrak lompong untuk mencit dengan berat badan 20 gram. Dosis tersebut dikonversikan dengan dosis untuk mencit sehingga dosis pemberian ekstrak lompong sebesar $13 \mathrm{mg} / 20 \mathrm{gBB} / \mathrm{hari}$.

Berdasarkan uraian di atas, peneliti ingin membuktikan potensi ekstrak lompong dengan pengukusan 45 menit dalam meningkatkan respon imun yang dilihat dari aktivitas fagositosis dan kadar NO makrofag sebelum dan sesudah diinduksi Listeria monocytogenes. Pemberian perlakuan ekstrak lompong 45 menit sebelum dan sesudah terinfeksi bertujuan untuk mengetahui kemampuan ekstrak lompong sebagai upaya preventif dan kuratif bagi penderita infeksi yang diakibatkan oleh bakteri intraseluler.

\section{METODE PENELITIAN}

Jenis penelitian ini merupakan penelitian true experimental dengan rancangan the post test with randomized control group design. Penelitian ini dilaksanakan di Laboratorium Penelitian dan Pengujian Terpadu (LPPT), Universitas Gajah Mada. Pelaksanaan penelitian ini telah mendapatkan persetujuan dari Komite Etik Fakultas Kedokteran Universitas Diponegoro melalui terbitnya Ethical Clearance (EC).

Subjek penelitian ini adalah mencit galur balb/c jantan dengan berat badan 20-30 gram pada usia 10 minggu dan dalam keadaan sehat yang diperoleh dari laboratorium Biologi Fakultas MIPA Universitas Negeri Semarang. Kriteria eksklusi penelitian ini adalah mencit sakit selama penelitian, mengalami perubahan perilaku (tidak lincah, tidak makan), dan tikus mati selama perlakuan. Pemilihan galur balb/c karena galur ini pada umur 6-12 minggu telah dilaporkan dapat menimbulkan respon imun selluler apabila mencit diinduksi dengan bakteri Listeria monocytogenes.

Berdasarkan Research Guidelines for Evaluation the Safety and Efficacy of Herbal Medicines dari WHO besar sampel untuk setiap kelompok minimal 5 ekor. ${ }^{11}$ Kemudian untuk mengantipasi adanya drop out, maka masingmasing kelompok terdiri dari 7 ekor. Total sampel 
yang digunakan dalam penelitian ini adalah 21 ekor. Sampel diambil sesuai dengan kriteria inklusi dan dilakukan secara acak. Sampel dikelompokan menjadi 3 kelompok yaitu kelompok kontrol (K), kelompok perlakuan 1 (P1) dan kelompok perlakuan 2 (P2). Kelompok K digunakan sebagai pembanding sehingga mencit hanya mendapatkan pakan standar dan diinduksi Listeria monocytogenes dosis $1 \times 10^{5} \mathrm{CFU}$. Kelompok P1, mencit mendapatkan ekstrak lompong 45 menit pengukusan dosis $13 \mathrm{mg} / 20 \mathrm{gBB}$ sebelum diinduksi Listeria monocytogenes dosis $1 \times 10^{5}$ CFU. Kelompok P2, mencit mendapatkan ekstrak lompong 45 menit pengukusan dosis $13 \mathrm{mg} / 20 \mathrm{gBB}$ setelah diinduksi Listeria monocytogenes dosis $1 \mathrm{x}$ $10^{5} \mathrm{CFU}$.

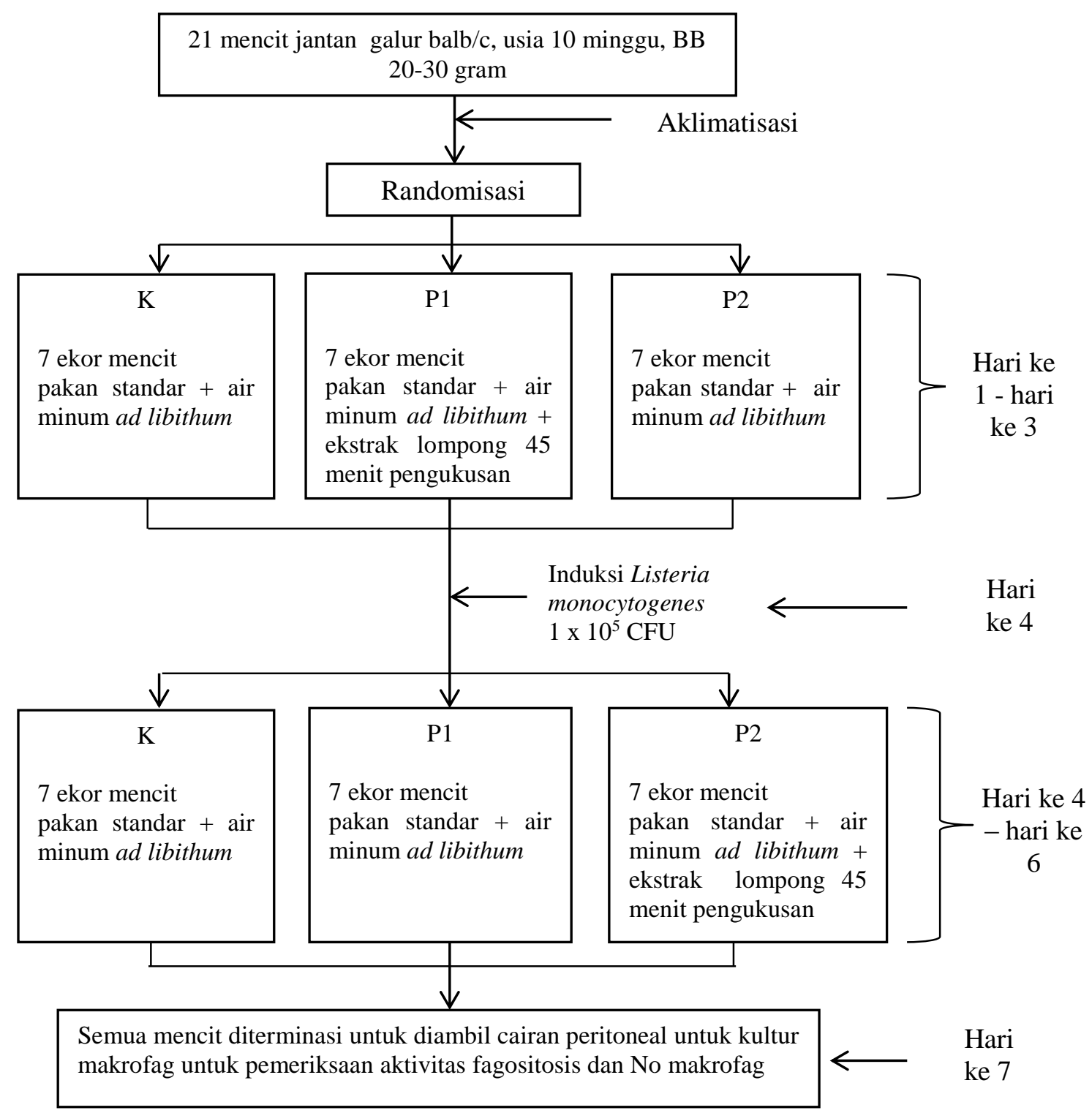

Gambar 1. Kerangka Kerja Penelitian

Variabel bebas pada penelitian ini adalah pemberian ekstrak lompong (Colocasia esculenta $L$. Schoot) 45 menit pengukusan dengan dosis 13 $\mathrm{mg} / 20 \mathrm{gBB}$ dan induksi Listeria monocytogenes dosis $1 \times 10^{5} \mathrm{CFU}$. Variabel terikat dalam penelitian ini adalah aktivitas fagositosis dan kadar Nitrit Oksida (NO) makrofag.

Pembuatan ekstrak lompong 45 menit pengukusan dilakukan di laboratorium Kimia
Organik Fakultas MIPA Universitas Diponegoro dengan metode ekstraksi sokletasi dengan menggunakan pelarut etanol.

Prosedur penelitian dalam penelitian ini adalah mencit jantan balb/c yang berumur 10 minggu dengan berat badan 20-30 gram sebanyak 21 ekor diadaptasikan selama 7 hari di laboratorium Parasitologi Universitas Diponegoro. Selama masa adaptasi mencit hanya mendapatkan pakan standar 
dan minum yang sama ad libitum. Pemberian ekstrak lompong 45 menit pengukusan diberikan dengan cara sonde pada hari pertama sampai hari ketiga untuk kelompok P1 dan hari keempat sampai hari keenam untuk kelompok P2. Penginduksian bakteri Listeria monocytogenes dilakukan secara intraperitoneal inokulum dengan dosis $10^{5} \mathrm{CFU}$. Setelah inokulasi bakteri hari ketujuh selama perlakuan, semua mencit diterminasi untuk diambil cairan peritoneal untuk pemeriksaan aktivitas fagositosis dan NO makrofag.

Pemeriksaan aktivitas fagositosis makrofag dinyatakan dengan indeks fagositik yaitu berupa presentase sel yang memfagosit latex yang dihitung pada 100 sel makrofag kali jumlah rata-rata partikel latex pada sel makrofag yang positif. ${ }^{12}$ Sedangkan kadar NO adalah jumlah NO yang terdapat pada supernatan kultur makrofag peritoneum yang diukur dengan menggunakan Metode Griess. Kemudian hasilnya dibaca absorbansinya menggunakan automated microplate reader (Elisa reader) pada panjang gelombang $550 \mathrm{~nm} .{ }^{13}$

Data yang telah terkumpul dianalisis dengan uji statistik. Semua data dilakukan uji normalitas terlebih dahulu dengan Shaphiro-Wilks karena jumlah sampel keseluruhan 21 ekor. Data berdistribusi normal, maka data dianalisis dengan independent $t$ test.

\section{HASIL DAN PEMBAHASAN}

Berdasarkan uji normalitas diperoleh nilai $p>0,05$ maka dapat disimpulkan bahwa data berdistribusi normal. Berikut ini merupakan hasil rerata indeks fagositosis dan kadar NO makrofag:

Tabel 1. Hasil Rerata Indeks Fagositosis dan Kadar NO Makrofag

\begin{tabular}{cccc}
\hline \multirow{2}{*}{ Kelompok } & \multirow{n}{*}{} & \multicolumn{2}{c}{ Rerata } \\
\cline { 3 - 4 } & 7 & Indeks Fagositosis & Kadar NO \\
\hline P1 & $7,42 \pm 0,54^{\mathrm{a}, \mathrm{b}}$ & $109,71 \pm 40,7^{\mathrm{c}}$ \\
P2 & 7 & $2,51 \pm 0,56$ & $101,71 \pm 45,03$ \\
K & 7 & $2,43 \pm 0,24$ & $106,29 \pm 54,39$ \\
\hline
\end{tabular}

Keterangan:

$\mathrm{a}=$ terdapat perbedaan bermakna antara kelompok sebelum diinfeksi Listeria monocytogenes dengan kelompok kontrol

$\mathrm{b}=$ rerata indeks fagositosis tertinggi pada kelompok sebelum diinfeksi Listeria monocytogenes

$\mathrm{c}=$ rerata kadar NO tertinggi pada kelompok perlakuan sebelum diinfeksi Listeria monocytogenes

Tabel 1 menunjukkan bahwa rerata indeks fagositosis kelompok perlakuan sebelum diinfeksi Listeria monocytogenes memiliki rerata lebih tinggi dibandingkan dengan kelompok perlakuan setelah diinfeksi dan kelompok kontrol yaitu 3,42 \pm 0,54. Kelompok perlakuan kontrol memiliki rerata indeks fagositosis paling rendah yaitu 2,43 $\pm 0,24$.

Rerata kadar NO pada tabel 1 menunjukkan bahwa rerata kadar NO tertinggi pada kelompok perlakuan sebelum diinfeksi jika dibandingkan dengan kelompok perlakuan setelah diinfeksi dan kelompok kontrol yaitu 109,71 $\pm 54,39 \mu \mathrm{M}$. Rerata kadar NO kelompok perlakuan setelah diinfeksi memiliki rerata kadar $\mathrm{NO}$ paling rendah yaitu $101,71 \pm 45,03 \mu \mathrm{M}$.

\section{Aktivitas Fagositosis Makrofag}

Kelompok perlakuan sebelum diinfeksi dengan kelompok kontrol menunjukkan bahwa terdapat perbedaan bermakna yaitu nilai $p=0,001$ $(p<0,05)$. Tidak terdapat perbedaan bermakna antara kelompok perlakuan setelah diinfeksi dengan kelompok kontrol yaitu nilai $p=0,725(p>0,05)$.

Peningkatkan aktivitas fagositosis pada kelompok perlakuan sebelum diinfeksi dengan kelompok kontrol sesuai dengan hipotesis penelitian. Hal ini dikarenakan ekstrak lompong 45 menit pengukusan mengandung senyawa alkaloid, saponin, tanin, flavonoid dan polifenol. Flavonoid dalam ekstrak lompong 45 menit pengukusan bermanfaat sebagai antiseptik, antikanker dan antioksidan. ${ }^{14}$ Senyawa flavonoid juga dapat meningkatkan respon imun.

Mencit Balb/c yang diinfeksi Listeria monocytogenes juga mempunyai usaha untuk pertahanan tubuh dengan mengaktifkan sel Natural Killer (NK) untuk memproduksi Interferon- $\gamma$ (IFN$\gamma$ ) sehingga dapat meningkatkan aktifitas bakterisidal makrofag dalam melawan bakteri. ${ }^{15}$ Pemberian ekstrak lompong 45 menit pengukusan mampu mengaktivasi makrofag. Flavonoid meningkatkatkan aktivitas IL-12 yang mengaktifkan sel NK, menstimulasi perkembangan sel Th-1 dan mengaktfikan sel $\mathrm{T} \mathrm{CD} 8^{+}$. Ketiga sel yang teraktivasi tersebut akan mempengaruhi Spesific Makrofag Activating factor (SMAF) yaitu molekul-molekul termasuk $\mathrm{IFN}_{-\gamma}$ yang dapat mengaktifkan makrofag sehingga makrofag mengalami peningkatan metabolik, motilitas dan aktivitas fagositosis dalam membunuh bakteri atau mikrooganisme patogen lainnya. ${ }^{16}$

Indeks fagositosis makrofag antara kelompok perlakuan setelah diinfeksi dengan 
kelompok kontrol tidak mengalami peningkatan secara statistik, tetapi jika dibandingkan dari rerata indeks fagositosis masing-masing kelompok maka antara kelompok perlakuan setelah diinfeksi dengan kelompok kontrol mengalami kenaikan. Hal ini dikarenakan pemberian ekstrak lompong 45 menit setelah diinfeksi bakteri Listeria monocytogenes kurang efektif jika hanya diberikan selama 3 hari atau pada hari keempat sampai hari keenam perlakuan setelah diinduksi Listeria monocytogenes. Selain mempunyai efek sebagai imunostimulan, falvonoid juga mempunyai efek sebagai imunosupresan yang dapat memungkinkan terjadinya hambatan aktivitas fagositosis makrofag. ${ }^{16}$

\section{Kadar Nitrit Oksida}

Kelompok perlakuan sebelum diinfeksi dengan kelompok kontrol dan kelompok perlakuan setelah diinfeksi dengan kelompok kontrol menunjukkan bahwa tidak terdapat perbedaan bermakna peningkatan kadar NO.

Pemberian ekstrak lompong 45 menit pengukusan tidak meningkatkan kadar NO secara signifikan, hal ini tidak sesuai dengan hipotesis penelitian. Perlawanan sistem imun teraktivasi karena bakteri intraselluler. Makrofag dan limfosit $\mathrm{T}$ saling bekerja sama untuk membunuh Listeria monocytogenes. Makrofag akan memfagosit bakteri dan limfosit $\mathrm{T}$ berdiferensiasi menjadi CD4 dan CD8. CD4 berdiferensiasi menjadi Th-1 yang kemudian menghasilkan sitokin IFN- $\gamma$. Sitokin tersebut akan mengaktifkan makrofag untuk menghasilkan senyawa salah satunya NO yang berperan membunuh bakteri. ${ }^{8}$

\section{Hubungan antara Indeks Fagositosis dan Kadar Nitrit Oksida (NO)}

Pemberian ekstrak lompong 45 menit pengukusan dengan perlakuan sebelum diinfeksi memiliki rerata indeks fagositosis dan kadar NO makrofag lebih tinggi dibandingkan dengan kelompok perlakuan setelah diinfeksi dan kelompok kontrol. Hal ini menunjukkan bahwa pemberian ekstrak lompong 45 menit pengukusan lebih efektif ditujukan sebagai usaha preventif.

Senyawa fenolik yang ada di ekstrak lompong 45 menit pengukusan dapat mengaktivasi makrofag karena dapat menstimulasi pelepasan IL12 dan IFN- - . Makrofag yang teraktivasi mengalami peningkatan aktivitas fagosit. ${ }^{17} \mathrm{NO}$ adalah produk yang dihasilkan oleh makrofag teraktivasi untuk membunuh patogen intrasel melalui jalur Reactive Nitric Intermediate (RNI). Peningkatan aktivitas fagosit makrofag juga akan mempengaruhi peningkatan kadar NO. Stimulasi makrofag oleh $\mathrm{IFN}_{-}, \mathrm{TNF}-\alpha$, Interluekin, Lipopolysaccharide (LPS) akan memacu transkripsi gen yang menyebabkan peningkatan kadar Nitric Oxide Synthase (NOS). Sekresi NO akan meningkat mengikuti peningkatan NOS. ${ }^{18} \mathrm{Hal}$ ini didukung dari hasil analisis uji kuantitatif ekstrak lompong 45 menit pengukusan yaitu phenol $0,222 \%$, tanin $0,310 \%$, dan flavonoid $0,140 \%$.

Hasil analisis uji kuantitatif, ekstrak lompong (Colocasia esculenta L. Schoot) mentah, 30 menit pengukusan dan 45 menit pengukusan sebagai berikut:

Tabel 2. Hasil Uji Kuantitatif Ekstrak Lompong Mentah, 30 menit Pengukusan dan 45 Menit Pengukusan

\begin{tabular}{|c|c|c|c|}
\hline \multirow{2}{*}{ Sampel } & \multicolumn{3}{|c|}{ Hasil Analisa } \\
\hline & Phenol (\%) & $\operatorname{Tanin}(\%)$ & Flavonoid (\%) \\
\hline Mentah $^{20}$ & 0,198 & 0,261 & 0,088 \\
\hline 30 menit pengukusan ${ }^{21}$ & 0,219 & 0,293 & 0,105 \\
\hline 45 menit pengukusan & 0,222 & 0,310 & 0,140 \\
\hline
\end{tabular}

Berdasarkan analisis uji kuantitatif, ekstrak lompong 45 menit pengukusan mempunyai kandungan fitokimia (phenol, tanin, dan flavonoid) lebih tinggi jika dibandingkan dengan ekstrak lompong mentah dan ekstrak lompong 30 menit pengukusan. Proses pengukusan mempengaruhi nilai kandungan fitokimia ekstrak lompong, semakin lama pengukusan semakin tinggi nilai kandungan fitokimia. ${ }^{22}$

Ekstrak lompong 30 menit pengukusan mempunyai kandungan fitokimia lebih tinggi daripada ekstrak lompong mentah. Proses pengukusan menyebabkan serat-serat yang terdapat pada ekstrak lompong menjadi lunak sehingga kelarutan komponen fitokimia juga berbeda. Hal ini menyebabkan serat-serat yang lebih lunak memudahkan komponen bioaktif yang terdapat pada ekstrak lompong mudah larut pada pelarutnya. $^{22}$

Berdasarkan penelitian yang sudah dilakukan, esktrak lompong 45 menit pengukusan lebih efektif digunakan sebagai tindakan preventif yaitu perlakuan sebelum diinfeksi dengan Listeria monocytogenes. Ekstrak lompong mentah lebih efektif digunakan sebagai tindakan kuratif yaitu perlakuan setalah diinfeksi dengan Listeria 
monocytogenes..$^{20}$ Sedangkan ekstrak lompong 30 menit pengukusan perlu diakukan penelitian lebih lanjut. $^{21}$

\section{SIMPULAN}

Pemberian ekstrak lompong (Colocasia esculenta L. Schoot) 45 menit pengukusan lebih efektif ditujukan sebagai usaha preventif yaitu pemberian ekstrak lompong 45 menit pengukusan sebelum diinfeksi dengan Listeria monocytogenes dalam meningkatkan aktivitas fagositosis dan kadar NO makrofag mencit Balb/c dibandingkan untuk kuratif yang diberikan setelah diinfeksi Listeria monocytogenes.

\section{SARAN}

Pemberian ekstrak lompong (Colocasia esculenta L. Schoot) 45 menit pengukusan dapat memberikan solusi alternatif sebagai tindakan preventif bagi penderita infeksi yang diakibatkan oleh bakteri intraselluler.

\section{UCAPAN TERIMAKASIH}

Puji syukur penulis panjatkan ke hadirat Allah SWT atas segala rahmat dan kemudahan yang telah diberikan-Nya. Ucapan terimakasih penulis ucapkan kepada pembimbing dr. Hesti Murwani Rahayuningsih, M.Si, Med atas bimbingan materi, para reviewer atas masukan untuk penelitian ini hingga dapat terlaksana sampai akhir, selain itu ucapan terimakasih penulis sampaikan kepada orang tua dan teman-teman yang telah memberi dukungan dan motivasi dalam penyusunan karya tulis ilmiah ini.

\section{DAFTAR PUSTAKA}

1. Savage GP, Mårtensson L, Sedcole JR. Composition Of Oxalates In Baked Taro (Colocasia Esculenta Var. Schott) Leaves Cooked Alone Or With Additions Of Cows Milk Or Coconut Milk. Journal of Food Composition and Analysis. 2009;22(1):83-86. Available at: http://linkinghub.elsevier.com/retrieve/pii/S08891 57508001397.

2. Amiruddin. Perubahan Sifat Fisik Talas (Colocasia esculenta L. Schoot) Selama Pengeringan Lapis Tipis [Skripsi]. Makassar: Universitas Hasanuddin. 2013.

3. Halligudi N. Pharmocological Potential of Calocasia an Edible Plant. Journal of drug Discovery and Therapeutics. 2013;1(2):5-9.

4. Lewu MN, Adebola PO, Afolayan AJ. Effect Of Cooking On The Proximate Composition Of The Leaves Of Some Accessions Of Colocasia Esculenta (L.) Schott In Kwazulu-Natal Province Of South Africa. African Journal of Biotechnology. 2009;8(8):1619-1622.
5. Chotimah S, Fajarini DT. Reduksi Kalsium Oksalat dengan Perebussan Menggunakan Larutan $\mathrm{NaCl}$ dan Penepungan untuk Meningkatkan Kualitas Sente (Alocasia marcrorrhiza) sebagai Bahan Pangan. Jurnal Teknologi Kimia dan Industri. 2013;2(2):76-83.

6. Istiqomah. Perbandingan Metode Ekstraksi Maserasi dan Sokletasi terhadap Kadar Piperin Buah Cabe Jawa (Piperis retrofracti fructus) [Skripsi]. Jakarta: Universitas Islam Negeri Syarif Hidayatullah. 2013.

7. Sagala RJ. Uji Imunomodulator Kombinasi Ekstrak Etanol Herba Meniran (Phyllantus niruri Linn.), Umbi Keladi Tikus (Thyphonium flagelliforme)(L.odd.) Blume, dan Daun Sirih Merah (Piper crocatum) terhadap Fagositosis Makrofag secara In Vitro [Skripsi]. Yogyakarta: Universitas Gajah Mada. 2013.

8. Ukhrowi U. Pengaruh Pemberian Ekstrak Etanol Umbi Bidara Upas (Merremia mammosa) terhadap Fagositosis Makrofag dan Produksi Nitrit Oksida (NO) Makrofag Studi pada Mencit Balb/c yang Diinfeksi Salmonella typhimurium [Tesis]. Semarang: Universitas Diponegoro. 2011.

9. Purnawati RD, Susilaningsih N, Ngestiningsih D. Aktifitas Fagositosis dan Produksi Nitrit Oksida Makrofag dari Mencit yang Diimunisasi Listeria Monocytogenes pada Pemberian Ganoderma Lucidum. Semarang: Universitas Diponegoro. 2002.

10. Munawaroh F, Sudarsono, Yuswanto. Pengaruh Pemberian Ekstrak Etanolik Daun Sembung (Blumeae Folium) terhadap Fagositosis Makrofag pada Mencit Jantan yang Diinfeksi dengan Listeria monocytogenes. Yogyakarta: Universitas Gajah Mada.

11. World Health Organization. Research Guidelines Evaluating the Safety and Efficacy Herbal Medicines. 1993.

12. Leijh PCJ, Furh RV, dan Zwet TLV. In Vitro Determination of Phagocyte and Intracellular Killing by Polymorphonuclear and Mononuclear Phagocyte. In: Weir DM Ed., Cellular Immunology. London: Blackwell Scientific Publication; 1986; 46.1- 46.21.

13. Dietert RR, Hotchkiss JH, Austic RE, Sung Y. Production of Reactive Nitrogen Intermediates by Macrophages. In: Methods in Immunotoxicology. Volume 2. editor : Burleson GR, Dean JH, Munson AE. A John Wilye Liss \& sons Inc Publ. New York. 1995; 99-1117

14. Putri D. Pengaruh Pemberian Ekstrak Lidah Buaya (Aloe vera) terhadap Proliferasi Limfosit pada Mencit Balb/c yang Diinfeksi Salmonella Typhimurium [Artikel Penelitian]. Semarang: Universitas Diponegoro. 2007.

15. Damayanti. Pengaruh Ekstrak Hedyotis corymbosa terhadap Aktivitas Fagositosis Makrofag Mencit Balb/c yang Diinfeksi Salmonella typhimurium 
[Artikel Penelitian]. Semarang: Universitas Diponegoro. 2005.

16. Dyah AN. Pengaruh Pemberian Ekstrak Buah Phaleria papuana terhadap Aktivitas Fagositosis Makrofag Mencit Balb/c [Artikel Penelitian]. Semarang: Universitas Diponegoro. 2006.

17. Surati. Pengaruh Ekstrak Daun Salam (Syzygium Polyanthum) terhadap Aktivitas Makrofag pada Mencit Balb/c yang Diinfeksi Salmonella Typhimurium [Tesis]. Semarang: Universitas Diponegoro. 2012

18. Adeputri TI. Pengaruh Pemberian Polifenol Teh Hijau Terhadap Sekresi Nitrit Oksida (NO) Sel Fagosit. [Proposal Penelitian]. Semarang: Universitas Diponegoro. 2006

19. Lewis JG. Isolation of Alveolar Macrophages, Peritoneal Macrophages, and Kupffer Cells. In: Methods in Immunotoxicology.Vol 2. Editor: Burleson GR, Dea n JH, Munson AE. New York. A John Wilye Liss \& sons Inc Publ. 1995;15-26

20. Sulistiani RP. Pengaruh Ekstrak Lompong Mentah (Colocasia esculenta L. Schoot) terhadap Aktivitas Fagositosis dan Kadar NO (Nitrit Oksida) Mencit Balb/c Sebelum dan Setelah Terinfeksi Listeria monocytogenes [Skripsi]. Semarang: Universitas Diponegoro. 2015

21. Sholikhah AR. Pengaruh Ekstrak Lompong (Colocasia esculenta L. Schoot) 30 Menit Pengukusan terhadap Aktivitas Fagositosis dan Kadar NO (Nitrit Oksida) Mencit Balb/c Sebelum dan Setelah Terinfeksi Listeria monocytogenes [Skripsi]. Semarang: Universitas Diponegoro. 2015

22. Nurjanah, Agoes MJ, Roni N, Marisa P, Tri KAS. Perubahan Komposisi Kimia, Aktivitas Antioksidan, Vitamin C dan Mineral Tanaman Genjer (Limnocharis flava) Akibat Pengukusan. September 2014:3(3)185-195 